\title{
CORRIGENDUM \\ Cryptosporidium parvum infections in a cohort of veterinary students in Sweden - CORRIGENDUM
}

P. KINROSS, J. BESER, K. TROELL, C. SILVERLÅS, C. BJÖRKMAN, M. LEBBAD, J. WINIECKA-KRUSNELL, J. LINDH AND M. LÖFDAHL

doi: http://dx.doi.org/10.1017/S0950268814003318. Published online: 30 January 2015.

There was an error in the author group of the above mentioned article [1].

The fourth author's name, C. SILVERLÅS, should have read C. AXÉN

The error has been rectified in the online and print PDF and HTML copies of the article.

\section{REFERENCE}

1. Kinross P, Beser J, Troell K, Silverlås C, Björkman C, Lebbad M, Winiecka-Krusnell J, Lindh J, Löfdahl M. Cryptosporidium parvum infections in a cohort of veterinary students in Sweden. Epidemiology and Infection. doi:10.1017/S0950268814003318. Published online: 30 January 2015. 